\title{
Better safe than sorry: leadership sensemaking in the time of COVID-19
}

\section{Filipe Sobral 1 \\ Juliana Carvalho 1 \\ Urszula Łagowska ${ }^{2}$ \\ Liliane Magalhães Girardin Pimentel Furtado ${ }^{3}$ \\ Miriam Grobman ${ }^{1}$}

${ }^{1}$ Fundação Getulio Vargas (FGV EBAPE) / Escola Brasileira de Administração Pública e de Empresas, Rio de Janeiro / RJ - Brazil 2 NEOMA Business School, Reims - France

3 Universidade Federal Fluminense / Programa de Pós-Graduação em Administração, Niterói / RJ - Brazil

Government leaders who want to promote a collective response to disrupting events, such as the COVID-19 pandemic, need to foster a shared understanding of the crisis through effective communication. However, the tone and content of communication varies across and within countries and led to conflicting results in terms of collective sensemaking. To understand how government leaders' messages shape emotional and cognitive responses of citizens, we designed a $2 \times 2$ vignette experiment in which we manipulate the framing (pessimistic vs. optimistic) and content of the message (specific vs. general) delivered by a political leader. Results from 436 participants showed that while the tone of leader's messages has significant implications for the levels of anxiety and evaluation of the government's truthfulness and its overall response to the crisis, the content of the leader's message matters less. Furthermore, these effects were particularly experienced by women and left-leaning participants. Overall, our results highlight the importance of the leader's communication strategies on influencing the public's emotional reactions, as well as the perceptions of government effectiveness in dealing with the crisis.

Keywords: COVID-19; leadership; sensemaking.

\section{Melhor prevenir do que remediar: 0 sensemaking da liderança nos tempos da COVID-19}

As lideranças governamentais que desejam promover uma resposta coletiva a eventos disruptivos, como a pandemia da COVID-19, precisam promover um entendimento compartilhado da crise por meio de uma comunicação eficaz. No entanto, o tom e o conteúdo de tais comunicações têm variado entre países e até dentro deles e demonstrado promover resultados conflitantes em termos de criação coletiva de sentido. Para entender como as mensagens das lideranças governamentais moldam as respostas emocionais e cognitivas dos cidadãos, desenvolvemos um experimento $2 \mathrm{x} 2$ com uso de vinhetas, no qual manipulamos o tom (pessimista $\mathrm{x}$ otimista) e o conteúdo da mensagem (específica x geral) emitida por uma liderança política. Os resultados de 436 participantes mostraram que, embora o tom da mensagem da liderança tenha implicações significativas para os níveis de ansiedade e para a avaliação da transparência do governo e da sua resposta geral à crise, o conteúdo da mensagem da liderança é menos importante. Além disso, esses efeitos foram particularmente sentidos por mulheres e participantes com inclinação política à esquerda. No geral, nossos resultados destacam a importância das estratégias de comunicação da liderança para influenciar as reações emocionais do público, bem como as percepções da eficácia do governo ao lidar com a crise.

Palavras-chave: COVID-19; liderança; sensemaking. 


\section{Mejor prevenir que curar: el sensemaking del liderazgo en los tiempos de COVID-19}

Los líderes gubernamentales que desean promover una respuesta colectiva a eventos disruptivos, como la pandemia de COVID-19, deben promover una comprensión compartida de la crisis a través de una comunicación efectiva. Sin embargo, el tono y el contenido de dicha comunicación han variado entre los diferentes países, e incluso dentro de éstos, y han demostrado que promueven resultados conflictivos en términos de creación colectiva de sentido. Para entender cómo los mensajes de los líderes gubernamentales determinan las respuestas emocionales y cognitivas de los ciudadanos, desarrollamos un experimento $2 \times 2$ usando viñetas, en el que manipulamos el tono (pesimista contra optimista) y el contenido del mensaje (específico contra general) emitido por un líder político. Los resultados de 436 participantes mostraron que si bien el tono del mensaje del líder tiene implicaciones significativas para los niveles de ansiedad y para la evaluación de la transparencia del gobierno y de su respuesta general a la crisis, el contenido del mensaje del líder es menos importante. Además, esos efectos los sintieron particularmente las mujeres y los participantes con un posicionamiento político de la izquierda. En general, nuestros resultados resaltan la importancia de las estrategias de comunicación de los líderes para influir en las reacciones emocionales del público, así como las percepciones de la eficacia del gobierno al enfrentar una crisis.

Palabras clave: COVID-19; liderazgo; sensemaking.

\section{BETTER SAFE THAN SORRY: LEADERSHIP SENSEMAKING IN THE TIME OF COVID-19}

"A leader is a dealer in hope" - Napoleon Bonaparte, French statesman and military leader (1769-1821).

The global pandemic of COVID-19 has caused unprecedented turmoil and posed tremendous challenges for government leaders around the world. In this moment of significant ambiguity and uncertainty, government leaders are responsible for managing the responses to the ongoing health and economic crises. As such, leaders must keep citizens informed of what is occurring and of what kind of actions are being undertaken by the administration to address these crises. In this context, an effective communication strategy emerges as a critical tool to mobilize the collective action needed to achieve the common interest of society (Ostrom, 2000), which is to contain the spread of the virus and thus minimize its social and economic consequences.

Public speeches such as press briefings and televised statements offer an opportunity for public leaders to convey their vision of the pandemic and, thus, influence the sensemaking process of the general population. Specifically, by shaping the meaning of the problems and guiding citizens' interpretation and understanding of the nature and effects of the evolving crisis (Boin, Kuipers, \& Overdijk, 2013), the government officials can yield citizens' support and cooperation in a collective, unified response (Hale, Dulek, \& Hale, 2005; Yang \& Ren, 2020).

The frames and content of the leaders' messages, however, vary across and even within countries. While some leaders have communicated using a more optimistic frame, others have employed a more pessimistic one. These distinct leader's communication styles have been a particular source of conflict in Brazil. Although most state governors and health authorities have delivered hard facts and focused their messages on the severity of the outbreak, others, notably Brazilian president Jair Bolsonaro, have attempted to minimize the risks posed by the virus and touted unverified treatments as potential remedies for the coronavirus disease (BBC, 2020).

Likewise, as political leaders are implementing a wide range of measures to mitigate the adverse economic impact of the COVID-19 outbreak, they need to communicate those to their constituents. 
In doing so, leaders can speak about their decisions in more general, abstract terms, or in more specific terms. In other words, while some leaders may communicate their actions in broad statements, others may explain in detail what measures they plan to implement.

Research on political leaders has shown that they are likely to adopt a more optimistic or pessimistic frame - which has been associated with a desire to avoid panic or to spur vigilance (Dember, 2002) - or communicate measures in a more general or specific fashion - as a way to appeal to a dissimilar audience or to reduce uncertainty and adjust expectations (Joshi \& Wakslak, 2013; Stephens, Malone, \& Bailey, 2005). However, scholars have argued that greater attention should be paid to how these different strategies of labeling and articulating the crisis may influence the audience (Larsson, 2016). Further, while public administration literature has mostly explored crisis response on the institutional level (Boin \& Lodge, 2016) or, in terms of singular events in the form of case studies (Comfort, 2007), questions remain concerning the influence and effectiveness of public leaders. The present research aims to address these issues by focusing on leadership as a process shaping the collective sensemaking in an extreme context of the COVID-19 outbreak. In particular, we contend that to understand citizens' sensemaking under the COVID-19 outbreak, we need to investigate their reactions to the messages issued by political leaders during the pandemic.

In the present paper, our goal is to understand how political leaders' messages in response to a disruptive crisis, such as the COVID-19 outbreak, shape citizens' emotional, cognitive, and behavioral responses. Specifically, we have designed a $2 \times 2$ vignette experiment in which we manipulate the framing (pessimistic vs. optimistic) and content of the message (specific vs. general) delivered by a political leader. We then measured participants' emotional response (anxiety) and their endorsement of government reaction, trust in government, and perception of government truthfulness.

We argue that by receiving different meanings and pieces of information, citizens will interpret and construct the reality in distinct ways, thus leading to varying reactions across the population (Gioia \& Chittipeddi, 1991). Considering that citizens' interpretations of and reactions to a crisis have consequences not only for their appraisals and feelings but also for their attitudes towards government reputation and leader electability (Lyon, 2004), we hope to provide important insights on the costs and benefits of communication strategies for political leaders in crises.

\section{LEADERSHIP SENSEMAKING UNDER CRISES}

Sensemaking refers to a process of social construction that takes place when individuals are faced with unforeseen events or confusing and discrepant pieces of information (Gioia \& Thomas, 1996; Maitlis \& Christianson, 2014; Weick, 1988). In other words, when confronted with ambiguous situations, people try to retrospectively make sense of the unfolding events, in order to rationalize them. To do that, individuals separate obtained informational cues into brackets and consequently interpret them by relying on cognitive frames that are salient to them in a given moment (Maitlis \& Sonenshein, 2010).

Leaders are critically important in the context of sensemaking under crises. This is because crises, defined as highly disruptive events of low probability, involve high levels of uncertainty and 
ambiguity, which make them be perceived as threatening to the existing organizations and relationships (Bundy, Pfarrer, Short, \& Coombs, 2017). Given the inherent ambiguity and ill-definition of crisis situations, the public is likely to struggle to interpret the situation. Besides, often erupting crises can expose limitations of public institutions and consequently undermine the legitimacy and political support for the government (Boin et al., 2016). In such contexts, the need for public leaders to engage in sensegiving, by projecting a vision of how to overcome a crisis (Mumford et al., 2007; Gioia \& Chittipeddi, 1991; Sonenshein, 2010), becomes imperative. First, because it gives the leaders a chance to establish support for the anti-crisis measures. Second, by using effective sensegiving frames in their communications with the public, leaders can avoid mass panic, facilitate collective sensemaking, and foster the adoption of the desirable behaviors by the citizens.

However, scholars have mentioned several challenges for leaders who want to shape the meaning in the fast-changing and threatening contexts. For instance, as main obstacles, the literature has cited communication issues and the use of competing information sources, such as mass media that may contradict the political leader's discourse (Boin et al., 2016; Maitlis \& Sonenshein, 2010). More importantly, prior studies on crisis communication have shown that depending on how the leader's message is crafted, it is likely to trigger distinct emotional, cognitive, and behavioral responses (e.g., Jin, 2010). Therefore, we argue that by assessing the emotional reactions to and evaluations of different sensegiving strategies employed by public leaders in the initial phases of the current COVID-19 crisis, we would be able to provide important insights on the effectiveness of such strategies for collective sensemaking. Specifically, in the present paper, we will compare the public's assessment of the frame (optimistic vs. pessimistic) and content (general vs. specific) of leaders' messages, which have been shown to produce conflicting results in terms of collective sensemaking.

\subsection{Optimistic vs. Pessimistic Frame}

When people have access to limited information, which is often the case during the initial phases of the crisis, they are likely to experience increased emotional stress and anxiety. To avoid mass panic, policymakers often choose to use optimistic frames when communicating with the citizens by either downplaying the seriousness of the problem or conveying crisis controllability (Boin et al., 2016). Indeed, research has suggested that positive communication frames can help to boost up the morale and positive emotions among the public members, leading to the emergence of shared mental models of the crisis (Liu \& Maitlis, 2014), more action-oriented thinking and psychological resources in the population (Fredrickson, 2001).

However, this can be a risky strategy for two main reasons. First, leaders who begin by shaping positive evaluations of crises in the beginning, may end up blinding themselves and others from important, contradictory pieces of information until it is too late to act upon them (Salancik \& Pfeffer, 1978; Weick \& Sutcliffe, 2003). Second, due to the inability of leaders to predict whether the crisis will escalate or not, they can be perceived as incompetent if they paint an overly positive picture of what will later be assessed as an unprecedented tragedy (Boin et al., 2016).

Contrastingly, some scholars have contended that a pessimistic frame is the most productive as it allows the leader to manage people's expectations and helps the public to prepare for the worst. Further, 
by harnessing people's anxiety or negative affect, a pessimistic frame can trigger a motivational goal of avoiding adverse outcomes among public members leading them to adopt preventive behavioral responses and thus increasing the likelihood of positive crisis resolution (Norem, 2007). Indeed, existing research has emphasized the functional value of pessimism in maintaining vigilant goal pursuit (e.g., Hazlett, Molden, \& Sackett, 2011). Finally, scholars have argued that although leader's positivity is likely to result in high psychological capital among followers (Avey et al., 2011), it can be ineffective when the followers perceive a leader's discourse as discrepant with their own experiences (Collinson, 2012). In such situations, followers can perceive the information source as dishonest and insincere, which is likely to diminish the overall support for the message and undermine trust for the government. As we predict that:

Hypothesis 1: Leader's pessimistic ( $v$ s. optimistic) frame will be positively related to the citizens' anxiety; however, it will be negatively related to citizens' perceptions of the government reactions to the crisis.

\subsection{General vs. Specific Information}

Another function of a leader's communication is to provide the public with information about the future steps the government will take to deal with the consequences of the crisis. These moments allow policymakers to shape people's understanding of how the administration envisions the future and assesses the feasibility of a much-desired comeback to normalcy. Specifically, the literature has suggested that public leaders can do so by engaging in vision communication through future-oriented, abstract in nature, idealizations of shared goals that are established by the leader (Conger \& Kanungo, 1994). This sensegiving strategy has been related to the perceptions of charisma, an important asset for the electability of political leaders (Jacquart \& Antonakis, 2010). Moreover, it has been shown that vision communication is perceived as particularly effective during periods of increased uncertainty, such as crises (Halevy, Berson, \& Galinsky, 2011). Also, previous research suggests that to connect with a disparate group of individuals within large audiences, communicators should frame messages in terms of superordinate characteristics that focus attention on the essence of the message (Wakslak \& Joshi, 2013).

However, vision communication rarely includes specific information about how the desired states will be obtained (Berson, Halevy, Shamir, \& Erez, 2015) and such lack of detail could be perceived by some as too vague and thus less effective in terms of creating the alignment between government and the public. Further, the goal-setting theory posits that goal specificity is an important characteristic that positively influences motivation towards the achievement of the desired state (Locke \& Latham, 2013). Indeed, numerous studies have shown that clear and specific goals are likely to elicit relatively more commitment and effort (Latham, Borgogni, \& Petitta, 2008; Pandey \& Wright, 2006). Moreover, communication research suggests that descriptive explanations and accurate details provided by specific language can reduce uncertainty and doubts (Larrimore, Jiang, Larrimore, Markowitz, \& Gorski, 2011). Thus, by providing information that is easy to understand, extract, and process as compared to general communication, specific language reduces cognitive stress, particularly in highrisk situations such as a pandemic. Consistently, we argue that clear and specific communication by the political leaders should promote the endorsement of the proposed measures among the general public. As such, we hypothesize: 
Hypothesis 2: Specific (vs. general) messaging will be negatively related to the citizens' anxiety; however, it will be positively related to citizens' perceptions of government reactions to the crisis.

Finally, although the effects of the frame and the content of leaders' messages can be considered independent, there are also reasons to believe that the combination of these different dimensions of a leader's message may trigger a distinct sensemaking process, leading citizens to respond differently. For example, relying on construal level theory, White, MacDonnell, and Dahl (2011) found a match-based effect between message framing (loss- versus gain-framed messages) with construal level (general/ abstract versus specific/concrete). Specifically, as gain-framed messages focus on attaining a desirable outcome (a high-level construal), they were more effective when matched with a mindset that stimulates abstract thinking; conversely, as loss-framed messages emphasize the costs associated with not choosing a particular option (a low-level construal), they were more persuasive when paired with a mindset that engages concrete thinking. As such, the present study will also investigate whether matching the frame of the leader's message (optimistic vs. pessimistic) with the content of the message (general vs. abstract) promotes specific modes of sensemaking and leads to more favorable reactions among constituents. Thus, we predict:

Hypothesis 3: The content of the leader's messaging (specific vs. general) will interact with the leader's frame (optimistic vs. pessimistic) to enhance the effects on citizens' anxiety and perceptions of the government reactions to the crisis.

\section{RESEARCH DESIGN AND METHOD}

This paper assesses two dimensions of the leader's communication in the face of the new Coronavirus pandemic. First, we evaluate the tone of the leader's message. Specifically, if they put emphasis on the negative aspects of the situation (pessimistic frame) or if they smooth out the problems, by acting in a hopeful and confident way about the future (optimistic frame). Then, we examine whether being specific or general about future actions and measures makes a difference in terms of citizens' reaction to the crisis.

To test those effects, we conducted a $2 \times 2$ survey experiment using an online platform. The survey was shared on social media, and for each response received, $\mathrm{R} \$ 1.00$ was donated to an emergency fund for health initiatives against Coronavirus (https://www.bsocial.com.br/causa/fundo-emergencial-forhealth-coronavirus-brazil). To make sure that participants would come from different backgrounds and represented a diverse sample of respondents, we targeted different social media groups, each with a different profile of participants. Data were collected from April 1st through April 7th.

In the first section of the survey, participants were randomly assigned to one of four scenarios: a pessimistic leader that conveyed a message with specific measures; a pessimistic leader with a message with general measures; an optimistic leader with concrete measures; and an optimistic leader with general measures. We then measured the impact of each scenario on people's anxiety levels, their confidence in the government, their assessment of the adequacy of the government's reaction, and their perception of the government's truthfulness. Finally, we collected some demographic information. We restricted the participation to Brazilian respondents, who were asked to imagine they lived in the fictitious town of Vale da Pedra, which had registered its first ten cases of COVID-19. After seeing this general message, participants were randomly assigned to our leadership scenarios. 
In the first condition, which we called pessimistic leader, participants received a message in which the mayor of Vale da Pedra talked about the seriousness of the situation, acknowledged that the worst was yet to come and ordered mandatory confinement of 14 days. Participants assigned to the second condition (optimistic leader) received a message in which the leader minimized the threat of the Coronavirus, saying there were reasons to be optimistic and that the majority of the population would get through it. Despite the mayor's positive assessment, he also ordered mandatory confinement of 14 days.

After reading our first manipulation, participants were, again, randomly assigned to one of two messages detailing the government's measures to mitigate the economic impact of the pandemic. The specific message explained that the town would provide aid to the unemployed and informal workers, suspend the payment of energy and water bills, and offer a credit line to small and micro companies. In contrast, the general message scenario did not specify any type of action, just mentioning that the city was planning to help its citizens and companies. Appendix A presents the vignettes for both manipulations.

After being presented with the scenarios, participants were asked to answer questions about our variables of interest. To measure participants' emotional reactions, we collected participants' responses on state anxiety. To this end, we used a 6-item scale adapted from Fioravanti-Bastos, Cheniaux, \& Landeira-Fernandez (2011). This scale asked participants to report how they would feel like residents of Vale da Pedra after receiving the mayor's messages. Response to items such as "I would feel worried" was given on a 5-point scale (Alpha: 0.88 ).

The items assessing trust in the government's actions ("How much do you trust the government of Vale da Pedra to take care of its citizens?"), approval of government reaction ("How do you assess the reaction of the Vale da Pedra government to the current Coronavirus outbreak"?), and perception government truthfulness ("How truthful do you think the Vale da Pedra government has been about the facts related to the coronavirus outbreak?") were adapted from the international survey Measuring Worldwide COVID-19 Attitudes and Beliefs (Caria et al., 2020) and were measured using a 5-point scale.

We also collected the following demographic information: sex, age, educational level, religiosity (measured using a five point-scale indicating frequency of attending religious events), political orientation (left or right), and the perception of financial losses resulting from the pandemic (4-point scale).

Our total sample was composed of $62 \%$ of women, and $59 \%$ of participants indicated they were politically aligned with the left. Regarding age, $50.4 \%$ of respondents were between 18 and 34; $37.6 \%$ were between 35 and 54; 12\% were above 55 years old. In terms of education, 7.3\% had high school degrees, $44.5 \%$ had a college degree, and $48.2 \%$ had post-graduate degrees. Over half of our sample $(50.5 \%)$ believed that the current pandemic would have a low impact on their financial lives, while $49.5 \%$ thought that the crisis would have a significant impact on their finances. Finally, 33.6\% of our participants were not religious, $43.1 \%$ declared mild levels of religiosity, and $24.2 \%$ high levels of religiosity.

Descriptive statistics show that 214 participants ( $49 \%$ of the sample) were assigned to the optimistic leader scenario, while 222 were assigned to the pessimistic leader. Moreover, 213 participants were randomly assigned to the general measures scenario ( $49 \%$ of the sample), and 223 were presented with the specific measures scenario. Table 1 presents the summary statistics of the variables in our study by scenario. As we can see in Table 1, the random assignment of participants to each condition yielded a balanced distribution of participants among the four experimental conditions. 


\section{TABLE 1 DESCRIPTIVE STATISTICS OF THE DEPENDENT VARIABLES}

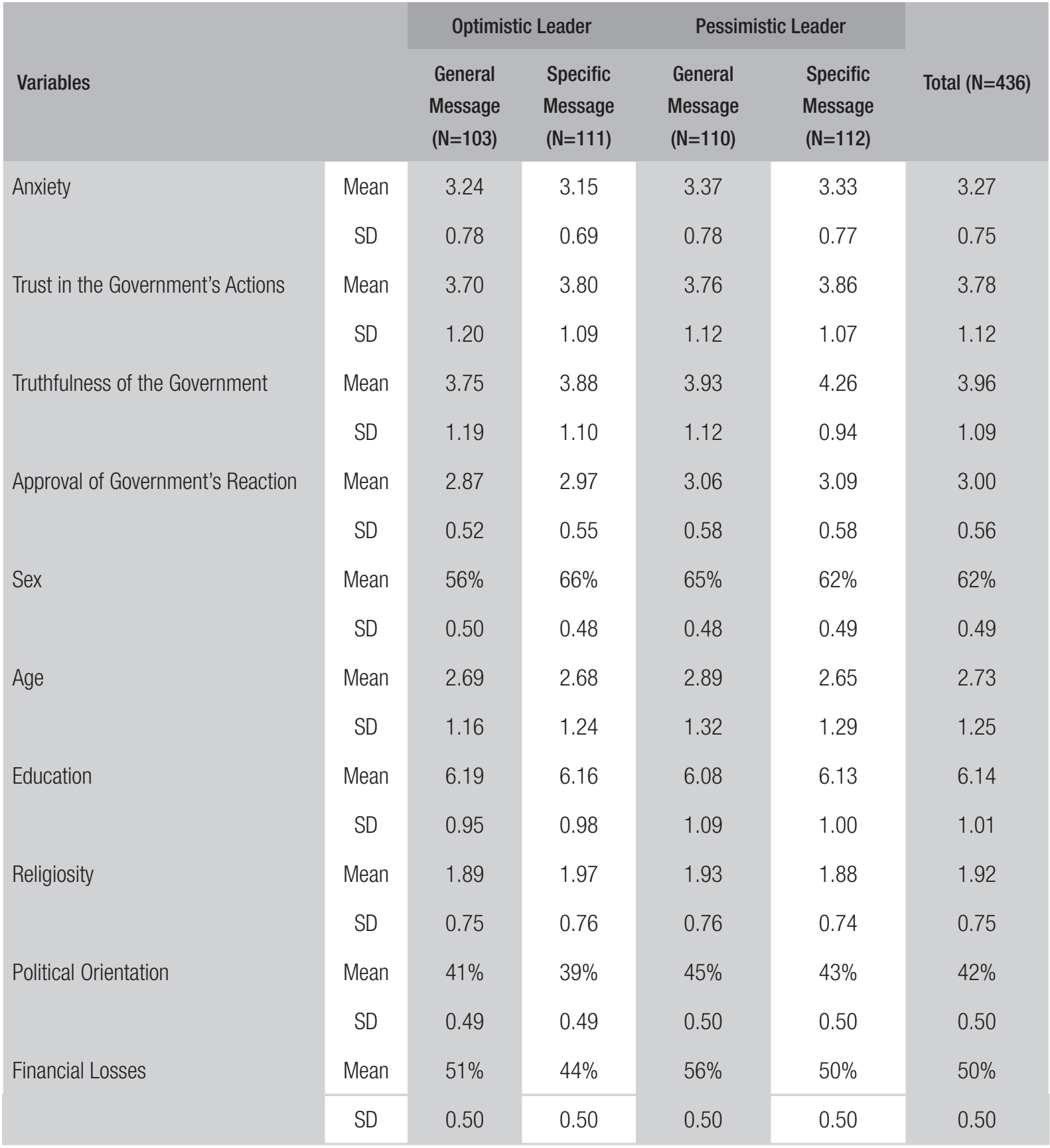

Note: Sex: $1=$ Female, $0=$ Male, Political Orientation: $1=$ Right, $0=$ Left, Financial losses: $0=$ High, $1=$ Low. Source: Elaborated by the authors. 


\section{MAIN RESULTS}

We analyzed the effects of the frame (pessimistic x optimistic) and content (specific $\mathrm{x}$ general) of the leader's message using multiple regressions. As can be seen in Table 2, we found a positive significant effect of the pessimistic tone on the participants' anxiety $(b=0.16$; S.E. $=0.07 ; p<0.05)$, such that the participants felt more anxious when presented with the pessimistic message $(M=3.35$; S.D. $=0.77)$, rather than the optimistic one $(M=3.19$; S.D. $=0.74)$. Nevertheless, we found no significant effects of the specificity of the proposed measures on anxiety.

Furthermore, we found a significant positive effect of the pessimistic frame on the approval of the government's reaction to the crisis $(b=0.15$; S.E. $=0.05, p<0.01)$. These results show that people who were presented with the leader using a pessimistic frame declared a higher approval of government measures $(M=3.08$; S.D. $=0.56)$ than the participants in the optimistic condition $(M=2.93$; S.D. $=0.53)$. There was no significant impact of the specificity of the proposed measures on approval of the government's reaction.

In addition, the analysis also revealed significant impact of the pessimistic frame $(b=0.31$; S.E. $=0.10, \mathrm{p}<0.01)$ on the perception of the government's truthfulness. Specifically, participants assigned to the pessimistic condition $(M=4.10$; S.D.=1.04) had a better perception of government honesty than the ones in the optimistic condition $(M=3.81$; S.D.= 1.15). Further, the results confirmed a significant impact of the specificity of the proposed measures on the perception of the government truthfulness $(\mathrm{b}=0.22$; S.E. $=0.10 ; \mathrm{p}<0.05)$, such that participants in the specific condition $(\mathrm{M}=4.07 ;$ S.D. $=1.05)$ evaluated government truthfulness higher than the ones in the general condition $(\mathrm{M}=3.84 ;$ S.D. $=1.16)$.

Moreover, we found no effect of either the tone of the leader's message or the specificity of proposed measures on the level of trust in the government's actions.

Overall, our results provided support to the effects of the leader's frame (H1), except for the effect on trust in the government, while only provided partial support to the effect of the content of the messaging (H2). Specifically, we only found a significant effect of the specific vs. general content on the perception of the government's truthfulness.

Finally, the interaction between the frame and content of the leader's message, as hypothesized in $\mathrm{H} 3$, yielded non-significant results for any of our dependent variables. Our main results are summarized in Table 2.

To examine whether the reactions to the leader's communication varied across subgroups, we segmented our sample according to the sex and political orientation of the respondents. Table 3 summarizes our results for these demographic groups. 
RAP | Better safe than sorry: leadership sensemaking in the time of COVID-19

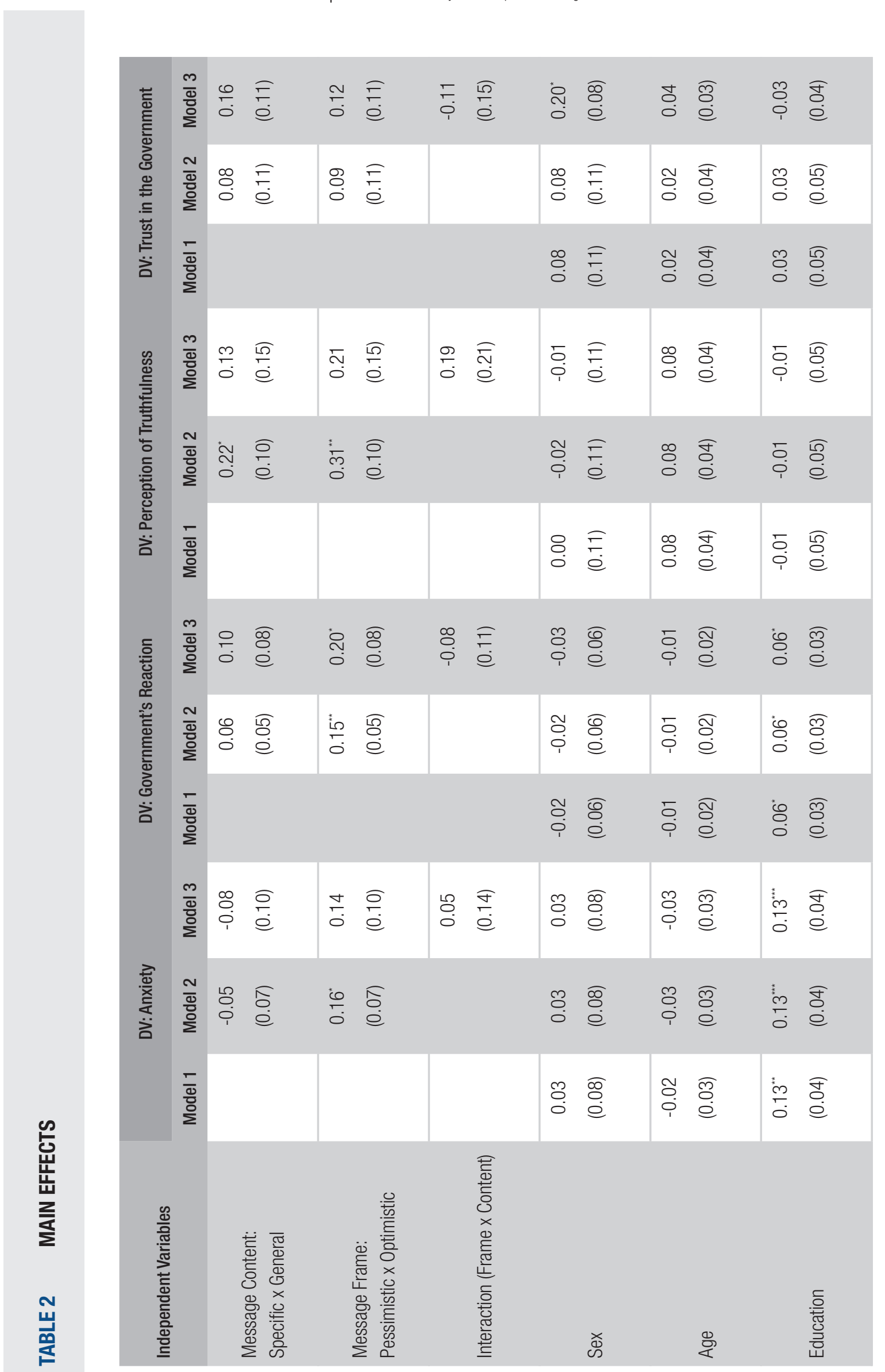

Brazilian JOURnal Of PUblic administration | Rio de Janeiro 54(4):758-781, July - Aug. 2020 


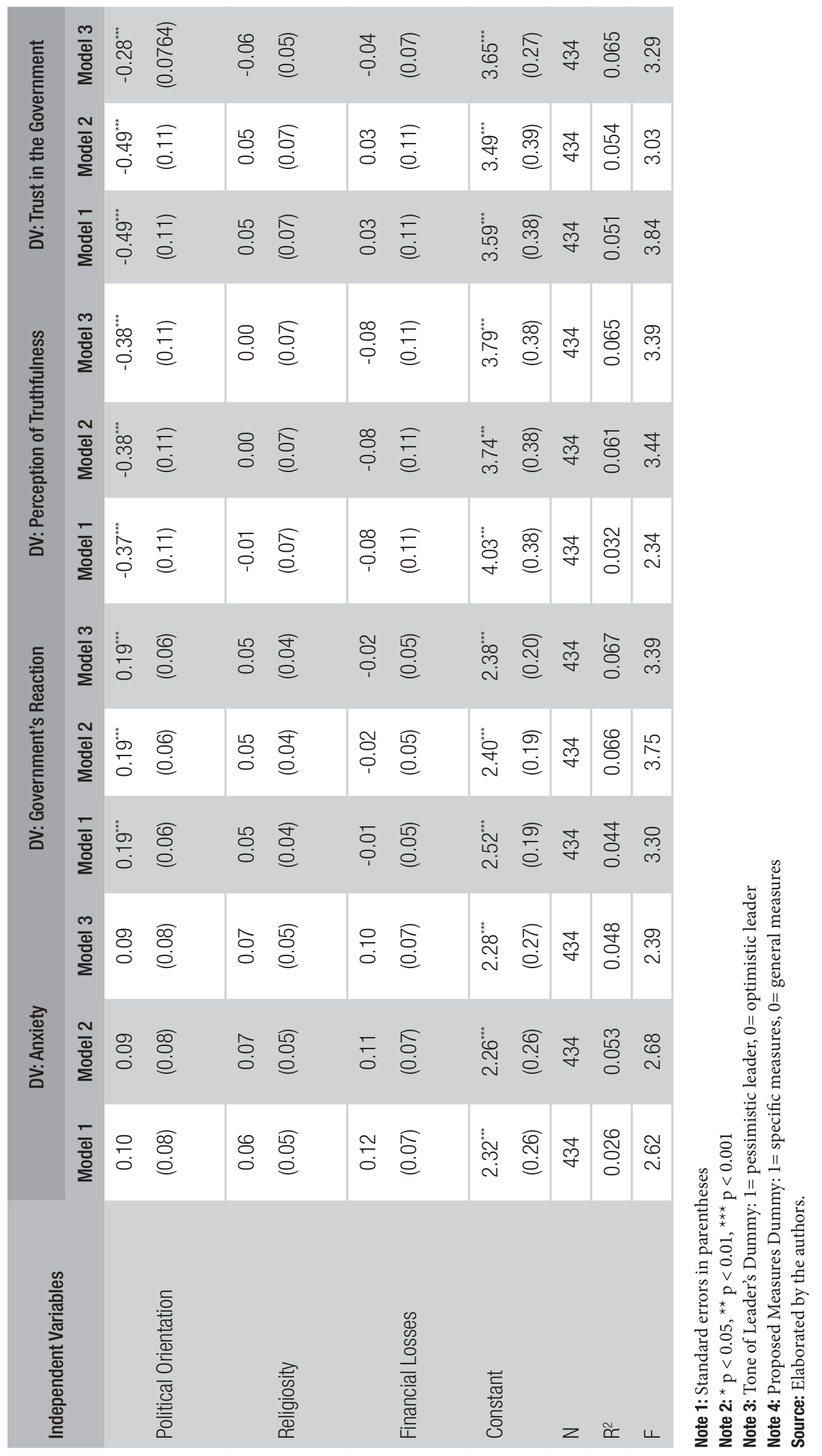


RAP | Better safe than sorry: leadership sensemaking in the time of COVID-19

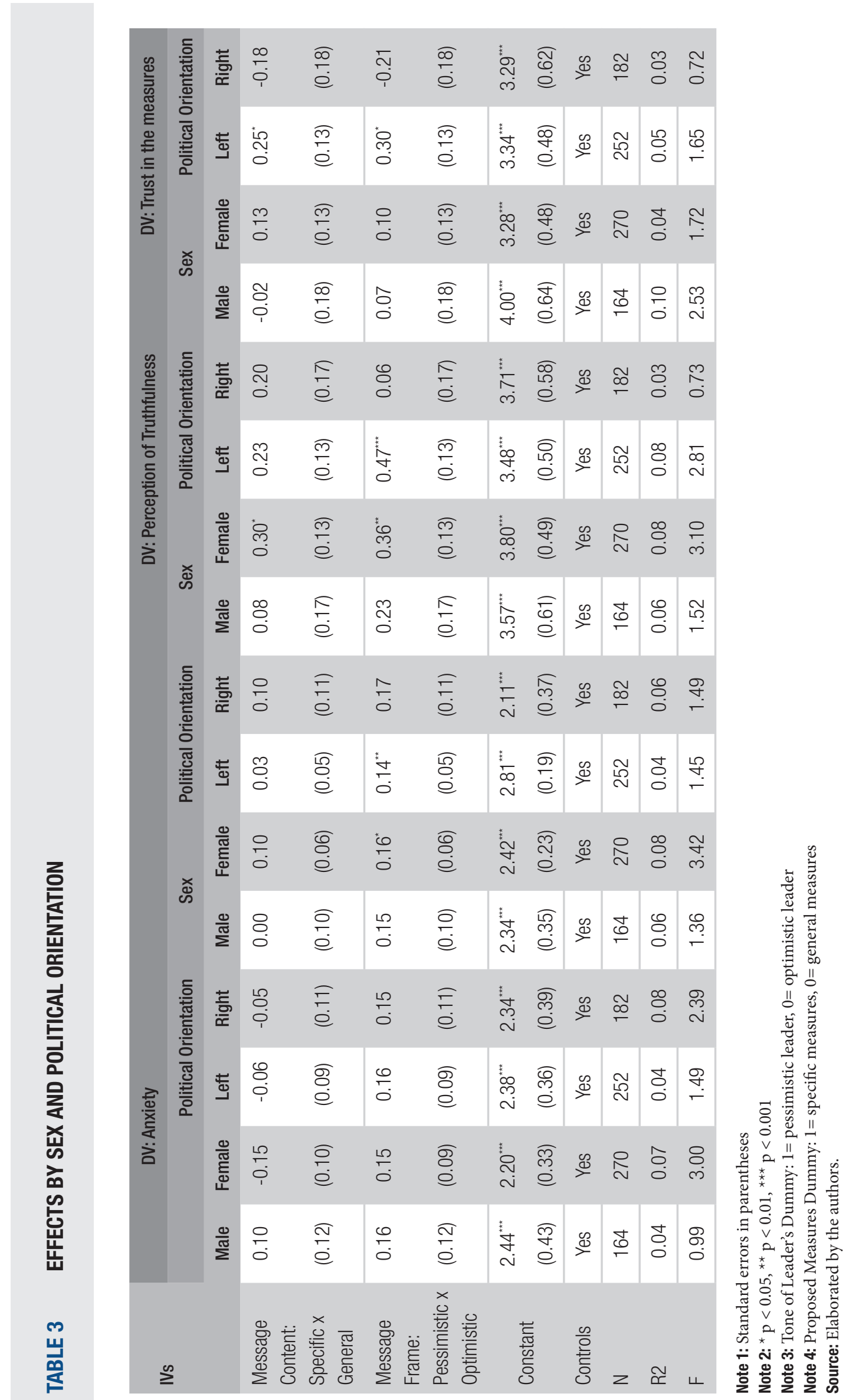

Brazilian JOURnal of PUblic administration | Rio de Janeiro 54(4):758-781, July - Aug. 2020 
Regarding the effect of the pessimistic vs. optimistic frame on the approval of the government's reaction across groups, we found a significant difference $(b=0.16$; S.E.: 0.06; $p<0.05)$ between women in the pessimistic frame condition $(\mathrm{M}=3.06$; S.D.= 0.50) and the ones exposed to the more optimistic leader message $(M=2.91$; S.D. $=0.53)$. Among men, we found no significant differences. Further, we found a significant effect among the respondents more leaning to the political left $(b=0.14$; S.E. $=0.05, \mathrm{p}<0.01)$. Our results show that people aligned with the left who saw the more pessimistic message evaluated the government's reaction as more appropriate $(M=2.99$; S.D. $=0.30)$ than the ones presented with the optimistic frame $(M=2.85$; S.D.= 0.47). However, we found no significant effect of the leader's tone on the approval of the government's reaction among the participants more aligned with the political right.

Regarding our results on the perception of government truthfulness, we observed a positive effect, among women, of both the tone of leader's message $(b=0.36$; S.E. $=0.13, p<0.01)$ and of the specificity of proposed measures $(b=0.30$; S.E. $=0.13, p<0.05)$. Specifically, as illustrated in Figure 1 , women in the pessimistic frame condition ( $\mathrm{M}=4.13$; S.D. $=1.06)$ perceived the government as more truthful than the ones in the optimistic frame scenario $(M=3.81$; S.D.=1.15), a difference of 8.39 percentage points. Further, the evaluation of the government truthfulness was higher among women who were exposed to the specific message $(M=4.11 ; S . D .=1.03)$ than those in the general message condition $(\mathrm{M}=3.82$; S.D. $=1.18)$. This difference of 7.59 percentage points was also significant (Figure 2). We found no significant effects of either one of our manipulations among male participants.

FIGURE 1 EFFECT OF LEADER'S FRAME ON THE PERCEPTION OF GOVERNMENT TRUTHFULNESS (BY SEX)

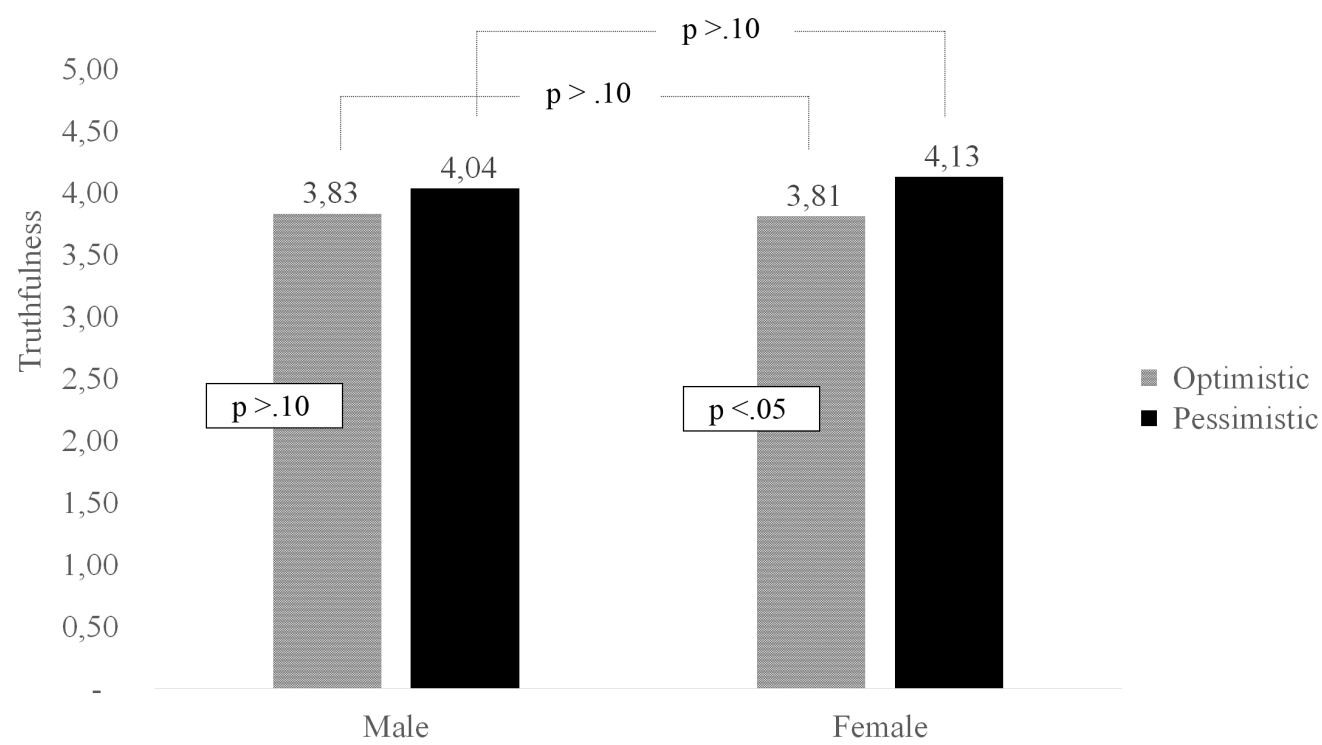

Source: Elaborated by the authors. 
FIGURE 2 EFFECT OF MESSAGE CONTENT ON THE PERCEPTION OF GOVERNMENT TRUTHFULNESS (BY SEX)

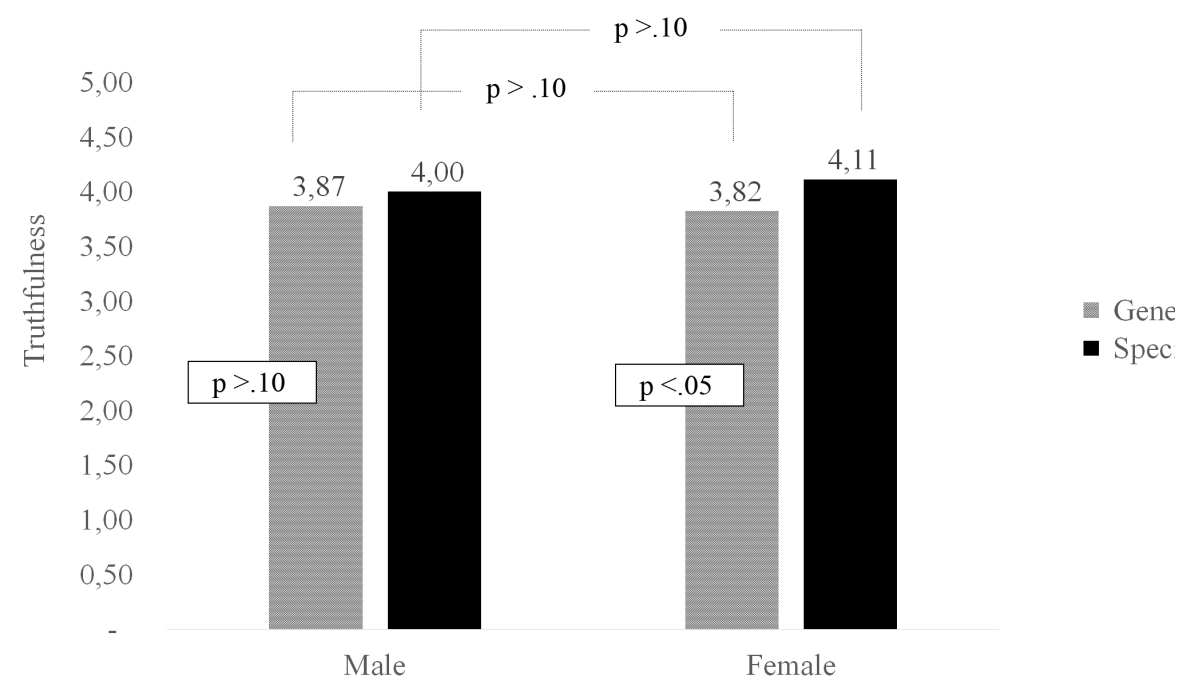

Source: Elaborated by the authors.

We also found an effect of political orientation on the relationship between the leader's tone and the perception of the government truthfulness among left-leaning participants $(b=0.47$; S.E. $=0.13, p<0.01)$. Specifically, we observed a 12.11 percentage points difference in the perception of government truthfulness between people in the pessimistic leader condition $(M=4.35$; S.D. $=0.95)$ and the ones in the optimistic condition $(\mathrm{M}=3.88$; S.E. $=1.12 ; \mathrm{b}=0.47$; S.E. $=0.13 ; \mathrm{p}<0,01)-$ see Figure 3. We found no effect of the message frame the perception of the government truthfulness among the right-leaning participants and no effect of the specificity of the message content among either right- or left-leaning respondents.

\section{FIGURE 3 EFFECT OF LEADER'S FRAME ON THE PERCEPTION OF GOVERNMENT TRUTHFULNESS} (BY POLITICAL-ORIENTATION)

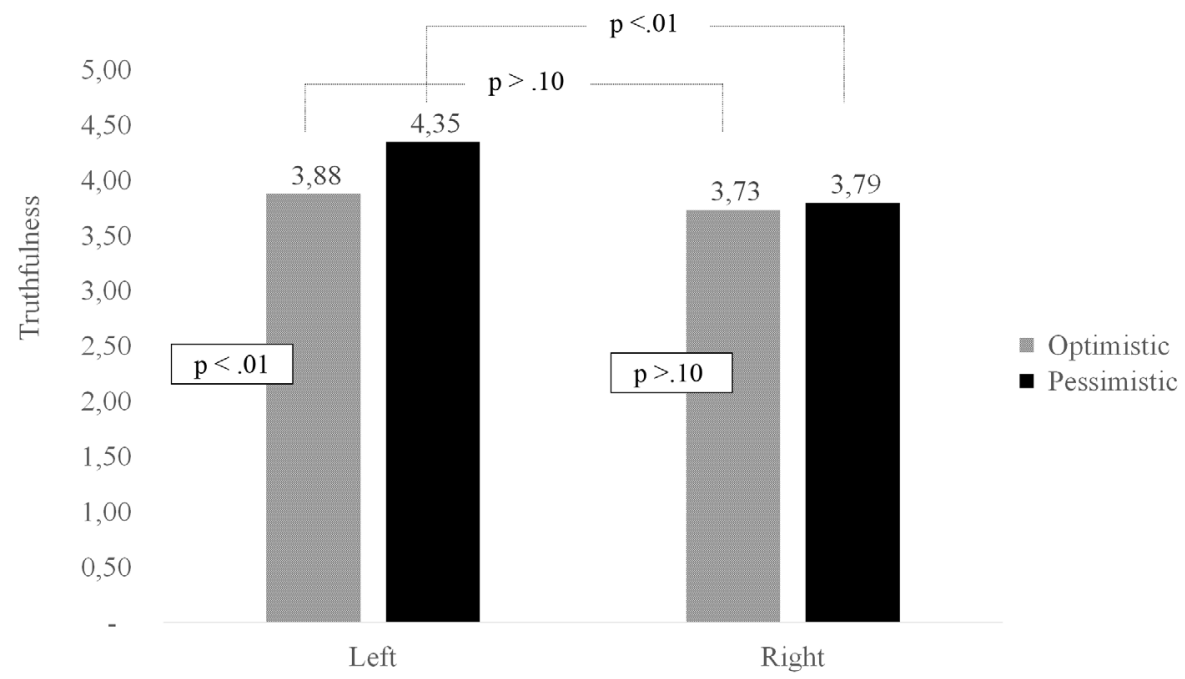

Source: Elaborated by the authors. 
Finally, we evaluated whether there were differences across gender and political orientation lines in terms of the impact of our scenarios on the trust in the government's actions. We found no significant effects of the tone of the leader or the message content between female and male respondents. However, we found significant effects between people aligned with the left and the right in both the frame of the leader's message $(b=0.30$; S.E. $=0.13, p<0.05)$ and the specificity of the message content $(b=0.25$; S.E. $=0.13, p<0.05)$. Left-leaning participants who saw the pessimistic leader $(\mathrm{M}=4.15, \mathrm{~S} . \mathrm{D} .=0.91)$ had a higher trust in the government than the ones in the optimistic scenario $(M=3.84$, S.D.=1.07). Also, people aligned with the left who were assigned to the specific message condition $(M=4.11$; S.D. $=0.86)$ indicated higher trust in the government's actions than the ones in the general condition $(M=3.87$; S.D.=1.13). Although we can observe an opposite effect on respondents aligned with the right, these effects were not significant for rightleaning participants. Figures 4 and 5 present these findings.

\section{FIGURE 4 EFFECT OF LEADER'S FRAME ON TRUST IN THE GOVERNMENT (BY POLITICAL ORIENTATION)}

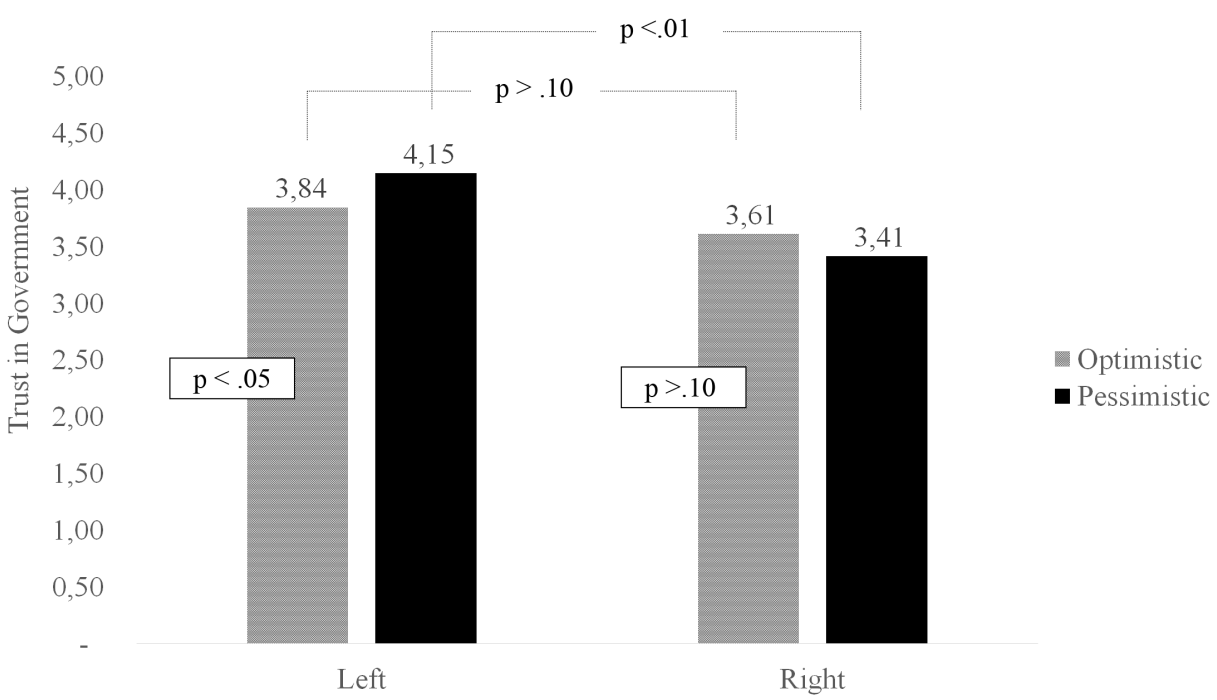

Source: Elaborated by the authors. 


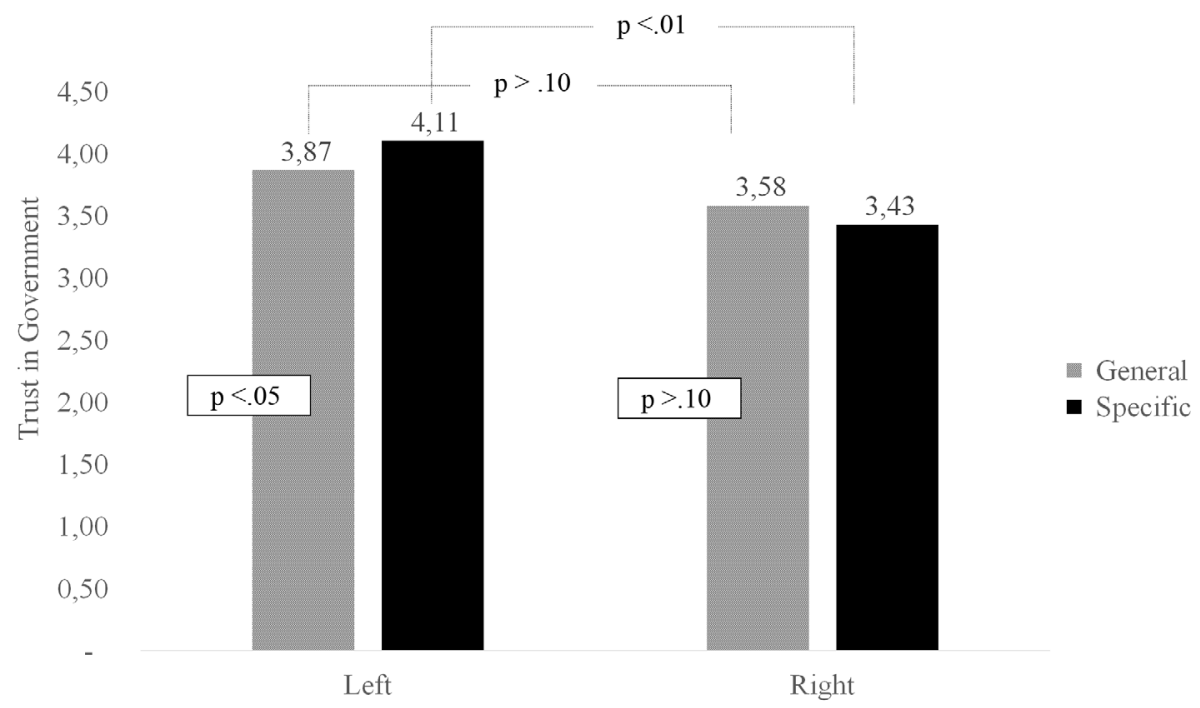

Source: Elaborated by the authors.

\section{DISCUSSION AND IMPLICATIONS}

Based on the sensemaking and sensegiving literature (Boin et al., 2016; Maitlis \& Sonenshein, 2010; Weick, 1988), government leaders who want to facilitate collective response to disrupting events, such as COVID-19 outbreak, need to foster a shared understanding of the crisis through effective communication (Ostrom, 2000). However, given that crises are often ultimate tests of political leaders' future electability and that they are confronted with a high level of uncertainty and ambiguity, the definition of the appropriate communication strategy constitutes a challenging task for anyone in a leadership position. Thus, in the present paper, we sought to evaluate the effectiveness of the leader's communication strategies about the COVID-19 ongoing crisis on the public's emotional and cognitive reactions.

Our results from an online survey experiment reveal that while the tone of the leader's message (optimistic vs. pessimistic) has significant implications for the levels of anxiety and evaluation of the government's truthfulness and its overall response to the crisis, the content of the leader's message (general vs. specific) matters less. On the one hand, the lack of a more robust effect of the message content might be related to the study design; on the other hand, it might be that the message content has more impact in later phases of the crisis when the constituents experience higher levels of financial distress and are more focused on the economic recovery. In any case, our results point to slightly higher effectiveness of specific, rather than general messaging, given that it increased the perception of the government's truthfulness, especially among women.

Another takeaway of the present study is related to the different consequences of the pessimistic frame. In particular, our findings suggest that focusing on the risks related to the pandemic is likely to lead to higher anxiety among the constituents, which has been previously linked with mixed outcomes. While research has shown that anxiety can be detrimental to the citizens' well-being (Puig-Perez et al., 2015), it can also increase individuals' efforts and vigilance towards the pandemic response 
and control. Further, we also find that using a pessimistic frame is conducive to higher ratings of the government's response and perceptions of its truthfulness. Therefore, our results seem to indicate that citizens prefer the leaders to outline a pessimistic scenario of the events, even if it makes them experience more anxiety. Our finding is relevant in the context of the still ongoing COVID-19 outbreak, as public leaders are faced with the possibility of the second wave of infections, and some of the elected officials have already started to play down the risk of the virus resurgence (Brett Samuels, 2020).

Contrary to our initial expectations, the interaction between the frame of the message and its content did not yield any significant results. This means that the match between a more optimistic and abstract message or a more pessimistic and specific one does not trigger different reactions among participants in response to the COVID-19 outbreak as previous research might have suggested (White et al., 2011). We conjecture that a possible explanation for this unexpected finding can be provided by the construal-level theory. According to this framework, hypothetical situations prompt individuals to experience psychological distance in relation to the described events, which means that their mental construals (how we shape things in our minds) of these situations tend to be more general rather than specific (Berson et al., 2015). Because we have used hypothetical vignettes to manipulate the content of the message, it may be that, regardless of whether the participants were exposed to specific or general the leader's message, the message content was interpreted in more general terms by participants in both conditions. This may have made it more difficult to observe that interaction effect.

Finally, it bears mentioning that we identified differences in the responses to the leader's communication during crises in specific demographics. In particular, our findings suggest that the pessimistic frame used by the leaders increased the evaluation of the government's reaction and the perception of the government's truthfulness among women and the participants more leaning to the left. Moreover, when the respondents who identified themselves as left-oriented were exposed to pessimistic and specific messages, they expressed more trust that the government would be able to tackle the pandemic. However, for the participants who were male or more aligned with the political right, the communication strategy employed by the leader yielded no effect.

These findings suggest two possible conclusions. First, gender plays a role in how citizens react to messaging about the crisis. Specifically, our findings are consistent with prior research showing that women are more likely to perceive risks and find them problematic (Slovic, 1999). As such, pessimistic messages emphasizing possible negative consequences of the pandemic are likely to resonate more with women rather than men. Second, the political orientation of the citizens forged before the beginning of the COVID-19 crisis clearly influences the public's reaction to the leader's communication during a critical event. This finding suggests that while fostering divisions among constituents can protect the elected officials from political scandals among a group of dedicated supporters (Iyengar, Lelkes, Levendusky, Malhotra, \& Westwood, 2019), this strategy is likely to backfire during crises such as the COVID-19 outbreak, which require shared understanding of the problem to foster the necessary collective action. Relatedly, the findings of our study yield important insights related to political polarization in Brazil, which has made the Coronavirus pandemic a "bloody battlefield". As Calvo and Ventura (2020) argue, public health policy has become a wedge issue that elicits partisan responses, which result in all kinds of strategies that narrow the focus of the public debate to "us" against "them". In other words, polarization has forged the construction of a blameless in-group 
opposed to a culprit out-group. It follows that citizens are expected to form favorable perceptions toward their in-group members (i.e., co-partisans) and hostile attitudes toward the out-group ones (i.e., opposing partisans). In a similar vein, political leaders are expected to shift and attribute blame and negative qualities to opponents while exempting allies of responsibility (Tilley \& Hobolt, 2011). Since the present study was not directed towards examining polarization effects, we attempted to portray a leader without ideological or political considerations. However, we acknowledge that it is tough to maintain a non-political or neutral stance in such polarized times. We believe that even small cues may have led participants to associate the leader portrayed in the study with "real leaders" and thus activate partisan identities and responses (Calvo \& Ventura, 2020). This could explain why our findings are strongly affected by respondents' political orientation. Nevertheless, it should be noted that even when controlling for political orientation, government leaders' messages have managed to significantly influence citizens' reactions. As such, our findings highlight the importance of leader sensemaking role during crises - even in extremely polarized contexts.

The present study is not without limitations. For instance, we acknowledge the limitations of our study related to the sample size and its composition. Nonetheless, we argue that given the random assignment to our experimental conditions and a very vivid context of the current pandemic, which has provided more authenticity to our hypothetical scenario, our results have high internal validity.

Besides, we recognize opportunities for future research related to leader sensemaking role during a crisis. Specifically, it would be interesting to examine what motivates public leaders to choose an optimistic or a pessimistic frame. On the one hand, it could be a result of the individual sensemaking processes of the leader, likely affected by individual biases and heuristics in an environment of enhanced uncertainty caused by a crisis (Tversky \& Kahneman, 1974). On the other hand, crises open space for actors who are willing to challenge the incumbent and offer a counternarrative (Boin, Hart, \& McConnell, 2009). Therefore, depending on how close the political leaders are to the election, they may choose to paint a rosier picture of the events to respond to the critiques. Future research could examine this possibility.

Taken together, our results point to the importance of the leader communication strategies during a crisis as they are likely to influence the public's emotional reactions to the situation, as well as the perceptions of the government's effectiveness in dealing with the crisis. Furthermore, the findings presented here reveal the deep political polarization of the Brazilian society and suggest that such divisions can become a significant obstacle for the leaders when they try to create a shared vision and promote collective action. 


\section{REFERENCES}

Avey, J. B., Avolio, B. J., \& Luthans, F. (2011). Experimentally analyzing the impact of leader positivity on follower positivity and performance. The Leadership Quarterly, 22(2), 282-294.

BBC. (2020, April 07). 'Gripezinha ou resfriadinho'e outras 7 frases controversas de líderes mundiais sobre o coronavírus. Retrieved from https://www.bbc.com/ portuguese/internacional-52205918

Berson, Y., Halevy, N., Shamir, B., \& Erez, M. (2015). Leading from different psychological distances: A construal-level perspective on vision communication, goal setting, and follower motivation. The Leadership Quarterly, 26(2), 143-155. Retrieved from https:// doi.org/10.1016/j.leaqua.2014.07.011

Boin, A., Hart, P., \& McConnell, A. (2009). Crisis exploitation: Political and policy impacts of framing contests. Journal of European Public Policy, 16(1), 81-106. Retrieved from https://doi. org/10.1080/13501760802453221

Boin, A., Kuipers, S., \& Overdijk, W. (2013). Leadership in times of crisis: A framework for assessment. International Review of Public Administration, 18(1), 79-91. Retrieved from https:// doi.org/10.1080/12294659.2013.10805241

Boin, A., \& Lodge, M. (2016). Designing resilient institutions for transboundary crisis management: A time for public administration. Public Administration, 94(2), 289-298.

Boin, A., Stern, E., \& Sundelius, B. (2016). The politics of crisis management: Public leadership under pressure. Cambridge, UK: Cambridge University Press.

Bundy, J., Pfarrer, M. D., Short, C. E., \& Coombs, W. T. (2017). Crises and crisis management: Integration, interpretation, and research development. Journal of Management, 43(6), 1661-1692. Retrieved from https://doi.org/10.1177/0149206316680030

Calvo, E. \& Ventura, T. (2020). Will I Get Covid? Partisanship, Social Media Frames, and Perceptions of Health Risk in Brazil (Working paper). Washington, DC: Inter-American Development Bank.

Caria, S., Fetzer, T., Fiorin, S., Goetz, F., Gomez, M., Haushofer, J. ... Yoeli, E. (2020, March 21).
Measuring Worldwide COVID-19 Attitudes and Beliefs. Charlottesville, VA: OSF. Retrieved from https://osf.io/3sn2k/

Collinson, D. (2012). Prozac leadership and the limits of positive thinking. Leadership, 8(2), 87-107.

Comfort, L. K. (2007). Crisis management in hindsight: Cognition, communication, coordination, and control. Public Administration Review, 67, 189197.

Conger, J. A., \& Kanungo, R. N. (1994). Charismatic leadership in organizations: Perceived behavioral attributes and their measurement. Journal of organizational behavior, 15(5), 439-452. Retrieved from https://doi.org/10.1002/job.4030150508

Dember, W. N. (2002). The optimism-pessimism instrument: Personal and social correlates. In E. C. Chang (Ed.), Optimism and pessimism: Implications for theory, research, and practice (pp. 281-299). Washington, DC: American Psychological Association.

Fioravanti-Bastos, A. C. M., Cheniaux, E., \& Landeira-Fernandez, J. (2011). Development and validation of a short-form version of the Brazilian state-trait anxiety inventory. Psicologia: Reflexão e Crítica, 24(3), 485-494. Retrieved from http://dx.doi. org/10.1590/S0102-79722011000300009

Fredrickson, B. L. (2001). The role of positive emotions in positive psychology: The broadenand-build theory of positive emotions. American Psychologist, 56(3), 218-226. Retrieved from https:// doi.org/10.1037/0003-066X.56.3.218

Gioia, D. A., \& Chittipeddi, K. (1991). Sensemaking and sensegiving in strategic change initiation. Strategic management journal, 12(6), 433-448. Retrieved from https://doi.org/10.1002/smj.4250120604

Gioia, D. A., \& Thomas, J. B. (1996). Identity, image, and issue interpretation: Sensemaking during strategic change in academia. Administrative science quarterly, 41(3), 370-403. Retrieved from https://doi. org/10.2307/2393936

Hale, J. E., Dulek, R. E., \& Hale, D. P. (2005). Crisis response communication challenges: Building theory from qualitative data. The Journal of Business Communication (1973), 42(2), 112-134. Retrieved from https://doi.org/10.1177/0021943605274751 
Halevy, N., Berson, Y., \& Galinsky, A. D. (2011). The mainstream is not electable: When vision triumphs over representativeness in leader emergence and effectiveness. Personality and Social Psychology Bulletin, 37(7), 893-904. Retrieved from https://doi. org/10.1177/0146167211402836

Hazlett, A., Molden, D. C., \& Sackett, A. M. (2011). Hoping for the best or preparing for the worst? Regulatory focus and preferences for optimism and pessimism in predicting personal outcomes. Social Cognition, 29(1), 74-96. Retrieved from https://doi. org/10.1521/soco.2011.29.1.74

Iyengar, S., Lelkes, Y., Levendusky, M., Malhotra, N., \& Westwood, S. J. (2019). The origins and consequences of affective polarization in the United States. Annual Review of Political Science, 22, 129-146. Retrieved from https://doi.org/10.1146/ annurev-polisci-051117-073034

Jacquart, P., \& Antonakis, J. (2010). Predicting presidential elections: It's the economy stupid, but charisma matters too. Montreal, Canada: Academy of Management, Organizational Behavior Division.

Jin, Y. (2010). Making sense sensibly in crisis communication: How publics' crisis appraisals influence their negative emotions, coping strategy preferences, and crisis response acceptance. Communication Research, 37(4), 522-552. Retrieved from https://doi.org/10.1177/0093650210368256

Joshi, P. \& Wakslak, C. (2013). Communicating with the Crowd: Speakers Use Abstract Messages When Addressing Larger Audiences. Journal of experimental psychology. General, 143(1), 351-352.

Larrimore, L., Jiang, L., Larrimore, J., Markowitz, D., \& Gorski, S. (2011). Peer to peer lending: The relationship between language features, trustworthiness, and persuasion success. Journal of Applied Communication Research, 39(1), 19-37. Retrieved from https://doi.org/10.1080/00909882. 2010.536844

Larsson, M. (2016). Leadership in interaction. London, UK: Routledge London.

Latham, G. P., Borgogni, L., \& Petitta, L. (2008). Goal setting and performance management in the public sector. International Public Management Journal, 11(4), 385-403. Retrieved from https://doi. org/10.1080/10967490802491087
Liu, F., \& Maitlis, S. (2014). Emotional dynamics and strategizing processes: A study of strategic conversations in top team meetings. Journal of Management Studies, 51(2), 202-234. Retrieved from https://doi.org/10.1111/j.14676486.2012.01087.x

Locke, E. A., \& Latham, G. P. (2013). Goal Setting Theory, 1990 Gary P. Latham and Edwin A. Locke. In E. A. Locke; \& G. P. Latham (Eds.), New developments in goal setting and task performance (pp. 27-39). London, UK: Routledge.

Lyon, L. (2004). A relational approach examining the interplay of prior reputation and immediate response to a crisis. Journal of Public Relations Research, 16(3), 213-241. Retrieved from https://doi. org/10.1080/1532-754X.2004.11925128

Maitlis, S., \& Christianson, M. (2014). Sensemaking in organizations: Taking stock and moving forward. Academy of Management Annals, 8(1), 57-125. Retrieved from https://doi.org/10.5465/19416520. 2014.873177

Maitlis, S., \& Sonenshein, S. (2010). Sensemaking in crisis and change: Inspiration and insights from Weick (1988). Journal of management studies, 47(3), 551-580. Retrieved from https://doi.org/10.1111/ j.1467-6486.2010.00908.x

Ostrom, E. (2000). Collective action and the evolution of social norms. Journal of Economic Perspectives, 14(3), 137-158. Retrieved from https:// doi.org/10.1257/jep.14.3.137

Pandey, S. K., \& Wright, B. E. (2006). Connecting the dots in public management: Political environment, organizational goal ambiguity, and the public manager's role ambiguity. Journal of Public Administration Research and Theory, 16(4), 511-532. Retrieved from https://doi.org/10.1093/ jopart/muj006

Puig-Perez, S., Villada, C., Pulopulos, M. M., Almela, M., Hidalgo, V., \& Salvador, A. (2015). Optimism and pessimism are related to different components of the stress response in healthy older people. International Journal of Psychophysiology, 98(2), 213-221. Retrieved from https://doi.org/10.1016/j. ijpsycho.2015.09.002

Salancik, G. R., \& Pfeffer, J. (1978). A social information processing approach to job attitudes 
and task design. Administrative science quarterly, 23(2), 224-253. Retrieved from https://doi. org/10.2307/2392563

Samuels, B. (2020, April 22). Trump says coronavirus "may not come back at all." The Hill. Retrieved from https://thehill.com/homenews/ administration/494229-trump-says-coronavirusmay-not-come-back-at-all

Slovic, P. (1999). Trust, emotion, sex, politics, and science: Surveying the risk-assessment battlefield. Risk analysis, 19(4), 689-701. Retrieved from https:// doi.org/10.1023/A:1007041821623

Sonenshein, S. (2010). We're changing - Or are we? Untangling the role of progressive, regressive, and stability narratives during strategic change implementation. Academy of Management Journal, 53(3), 477-512. Retrieved from https://doi. org/10.5465/amj.2010.51467638

Stephens, K. K., Malone, P. C., \& Bailey, C. M. (2005). Communicating with stakeholders during a crisis: Evaluating message strategies. The Journal of Business Communication (1973), 42(4), 390-419. Retrieved from https://doi.org/10.1177/0021943605279057

Tilley, J., \& Hobolt, S. B. (2011). Is the government to blame? An experimental test of how partisanship shapes perceptions of performance and responsibility. Journal of Politics, 73(2), 316-330. Retrieved from https://doi.org/10.1017/S0022381611000168

Tversky, A., \& Kahneman, D. (1974). Judgment under uncertainty: Heuristics and biases. Science,
185(4157), 1124-1131. Retrieved from http://doi. org/10.1126/science.185.4157.1124

Yang, L., \& Ren, Y. (2020). Moral Obligation, Public Leadership, and Collective Action for Epidemic Prevention and Control: Evidence from the Corona Virus Disease 2019 (COVID-19) Emergency. International Journal of Environmental Research and Public Health, 17(8), 2731. Retrieved from https:// doi.org/10.3390/ijerph17082731

Wakslak, C., \& Joshi, P. D. (2013). Communicating with the Crowd: Speakers use Abstract Messages when Addressing Larger Audiences. Academy of Management Proceedings, 2013(1), 12908. Retrieved from https://doi.org/10.5465/ ambpp.2013.12908abstract

Weick, K. E. (1988). Enacted sensemaking in crisis situations. Journal of Management Studies, 25(4), 305-317. Retrieved from https://doi. org/10.1111/j.1467-6486.1988.tb00039.x

Weick, K. E., \& Sutcliffe, K. M. (2003). Hospitals as cultures of entrapment: a re-analysis of the Bristol Royal Infirmary. California Management Review, 45(2), 73-84. Retrieved from https://doi. org/10.2307/41166166

White, K., MacDonnell, R., \& Dahl, D. W. (2011). It's the mindset that matters: The role of construal level and message framing in influencing consumer efficacy and conservation behaviors. Journal of Marketing Research, 48 (3), 472-485. Retrieved from https://doi.org/10.1509/jmkr.48.3.472 


\section{Filipe Sobral}

https://orcid.org/0000-0002-9900-9464

Associate Professor at the Brazilian School of Public and Business Administration at Fundação Getulio Vargas (FGV EBAPE).E-mail: filipe.sobral@fgv.br

\section{Juliana Carvalho}

https://orcid.org/0000-0001-8434-7594

Ph.D. student in Administration at the Brazilian School of Public and Business Administration at Fundação Getulio Vargas (FGV EBAPE). E-mail: juliana.carvalho.1@fgv.edu.br

\section{Urszula Łagowska}

(D)

https://orcid.org/0000-0003-4137-8037

Professor at NEOMA Business School. E-mail: ula.lagowska@gmail.com

\section{Liliane Magalhães Girardin Pimentel Furtado}

\section{https://orcid.org/0000-0003-3510-8321}

Professor in the Graduate Program in Administration at Universidade Federal Fluminense (UFF).

E-mail: lilianempf@gmail.com

\section{Miriam Grobman}

https://orcid.org/0000-0002-4527-7834

Ph.D. student in Administration at the Brazilian School of Public and Business Administration at Fundação Getulio Vargas (FGV EBAPE). E-mail: grobmanm@gmail.com 


\section{APPENDIX - VIGNETTES}

\section{1) FRAME OF LEADER'S MESSAGE}

\section{1) Pessimistic:}

"Given the situation (the pandemic), the mayor of Vale da Pedra organized a press conference where he said the following: I want you to know that the situation we are in is very serious. So far, the number of cases has been relatively low. However, the worst is yet to come. I wish I could say that we're all going to be fine, but unfortunately, I can't.

According to the data we have, the vast majority will contract COVID-19, many of whom will have mild symptoms. Still, some will be hospitalized, and, unfortunately, many people will die in this pandemic.

To prevent the virus from spreading, I ordered mandatory confinement for the next 14 days. During this time, all residents are prohibited from leaving their homes, except to go to the grocery store or pharmacy. Also, all non-essential businesses must remain closed during this period."

\section{2) Optimistic:}

"Given the situation (the pandemic), the mayor of Vale da Pedra organized a press conference where he said the following: I want you to know that the situation we are in is not so serious. So far, the number of cases has been relatively low. So, we have reason to be optimistic.

The vast majority will be fine, and we will get through it. According to the data we have, the vast majority of people will contract COVID-19. However, almost everyone will be asymptomatic or have mild symptoms like the flu. Only people of age or pre-existing illnesses are at more serious risk.

In order to prevent the virus from spreading, I ordered mandatory confinement for the next 14 days. During this time, all residents are prohibited from leaving their homes, except to go to the grocery store or pharmacy. Also, all non-essential businesses must remain closed during this period."

\section{2) CONTENT OF THE LEADER'S MESSAGE:}

\section{1) Specific Measures:}

"When asked about the next measures, the mayor of Vale da Pedra stated:

I would like to assure you that I am aware of the impact of these measures on the local economy. Therefore, I would like to inform you that the city will transfer R $\$ 1,000$ to the unemployed, informal workers, and other people in vulnerable situations with low income, in addition to suspending the payment of energy and water during the pandemic for all workers. I will also open a credit line of $\mathrm{R} \$ 1$ million for each small and micro company that will suffer because of this crisis. No company will go bankrupt because of the Coronavirus." 
RAP | Better safe than sorry: leadership sensemaking in the time of COVID-19

\section{2) General Leader's Measures:}

"When asked about the next measures, the mayor of Vale da Pedra stated:

I would like to assure you that I am aware of the impact of these measures on the local economy. So, I would like to tell you that the city will help businesses and workers to deal with the consequences of this crisis. No company will go bankrupt because of the Coronavirus." 